\title{
Conservatisme in vooroorlogs Nederland
}

\author{
H. W. VON DER DUNK
}

In NRC-Handelsblad van 13 april 1973 en elders ${ }^{1}$ heeft J. L. Heldring de afwezigheid betreurd van een duidelijk filosofisch gefundeerd conservatisme in de Nederlandse samenleving. De politieke discussie was daardoor verstoken gebleven van een wezenlijk element en bleef onvolgroeid. Heldring haalt in dit verband nog Nolens aan, die volgens een herinnering van P. J. Oud in 1917 in de kamer gezegd schijnt te hebben 'dat er liever mensen beschuldigd zouden worden van diefstal of brandstichting dan van het feit, dat ze conservatief en geen demokraat zouden zijn' $^{2}$. Huizinga heeft zich in 1934 in dezelfde geest uitgelaten en de absentie van conservatisme als een gemis gevoeld in het politieke spectrum. Conservatief betekende in Nederland zoveel als bekrompen en achterlijk en

deze vrees om ouderwetsch te schijnen (bewijs van burgerlijkheid in den slechten zin) heeft in ons land de ontwikkeling van het politieke leven zeer tot schade gestrekt. Het ware te wenschen geweest, dat een groep van politiek geschoolden den moed hadde bezeten, zich conservatief te blijven noemen, conservatief in den waardigen zin van het goede te willen behouden en de traditie niet roekeloos te willen prijsgeven voor de mode van den $\mathrm{dag}^{3}$.

We kennen inderdaad in onze eeuw geen partij of stroming in Nederland die vrijwillig het adjectief 'conservatief' draagt. De term lijkt een gore, versleten hoed, waar niemand het hoofd mee wenst te bedekken. Hoogstens probeert men hem tegenstanders onverhoeds over de oren te drukken.

Wie nu de recente literatuur over het Nederland van voor de oorlog openslaat, krijgt echter allerminst de indruk van een land dat blaakte van dynamiek en ongeduldige vernieuwingsdrang, zoals men op grond van Nolens uitspraak op het eerste gezicht zou verwachten. Integendeel, juist de laatste tijd hebben we in verschillende publicaties van meer populaire of bloedserieuze aard kunnen lezen, hoe

* Dit artikel berust op een lezing, die tijdens het Nederlands-Belgisch historisch congres te Leuven op ljuni 1973 werd gehouden.

1. NRC-Handelsblad, 13 april 1973, rubriek 'Dezer dagen'. Vergelijk ook J. L. Heldring, 'Lof van het conservatisme' in Liberaal Réveil, april 1974.

2. P.J. Oud in Elseviers Weekblad, 1 april 1967. Ik dank dit gegeven aan J. L. Heldring. Zie ook P.J. Oud, Het jongste verleden (Assen, 1948) I, 25.

3. J. Huizinga, Nederlands geestesmerk in: Verzamelde Werken (9 dln; Haarlem, 1948-1953) VII, 303.

BMGNWafl.l. 


\title{
H. W. VON DER DUNK
}

statisch en ouderwets het land van koningin Wilhelmina en Colijn, van de vijfvoudige omroep en het belastingplaatje was. Een lucht van arteriosclerose en verzuiling zou ons tegemoet waaien, als het woord 'waaien' op zichzelf al niet in strijd was met de bedoelde windstilte. 'Een conservatief land' noemt L. de Jong het kortweg in zijn lange Voorspel4. Die voorstelling wordt door tal van memoires bevestigd, ook al zijn we nog niet overmatig gezegend met dit genre in Nederland. Memoires wel te verstaan van de generatie, die de vooroorlogse periode als kind of adolescent heeft meegemaakt en die dan ook gauw geneigd is om met de maatstaf van het naoorlogse Nederland te meten. Die maatstaf is natuurlijk discutabel. Maar dat Nederland over het geheel genomen een stille vijver was, een natie, die zich door dijken niet alleen tegen de zee, maar vooral tegen de moderne tijd beschermde, blijkt juist uit de zinvollere vergelijking met de omliggende landen. De 'roaring twenties', 'die goldenen zwanziger Jahre' - een vast begrip - ik zou niet willen beweren dat er helemaal geen echo in Nederland van te vinden zou zijn. Maar de generatie die met tranen in de ogen aan dat decennium terugdenkt als aan een eenmalige explosie van energie, culturele vernieuwing, idealisme en experimenteren is in Nederland afwezig; omdat niemand blijkbaar zich een explosie kan herinneren. Veel representatiever voor de geest, die het jonge evenals het oudere geslacht toen beheerste, is stellig het lied, dat talloze malen door talloze christelijke verenigingen werd uitgegalmd:

\author{
Zy zullen het niet hebben \\ ons oude Nederland! \\ Het bleef by alle ellenden \\ Gods en der Vaad'ren pand! \\ Zy zullen het niet hebben \\ De goden van den tijd! \\ Niet om hun erf te wezen, \\ heeft God het ons bevryd ${ }^{5}$ !
}

'Conservatief' wilde niemand heten. Maar tallozen zongen luidkeels met Da Costa, dat Nederland niet ten prooi zou vallen aan 'de goden van den tijd'!

Hoe dit gangbare beeld van een traditionalistisch en anti-modern georiënteerde samenleving te rijmen met de afwezigheid van een geprofileerde conservatieve partij of ideologie? Het antwoord lijkt voor de hand te liggen: waar allen conservatief zijn, behoeft niemand zich uitdrukkelijk zo te noemen. Nederland zou dan een verlaat schoolvoorbeeld vormen van Hugh Cecils stelling, dat het conservatisme in Europa pas zichtbaar werd toen de statische samenleving door de Verlichting en de Franse revolutie was doorbroken. Daarvóór was het immers onmogelijk 'to

4. L. de Jong, Het koninkrijk der Nederlanden in de tweede wereldoorlog, I (Den Haag, 1969) 72. 5. Uit Isaac da Costa, 'Aan Nederland, in de lente van 1844', in: J. P. Hasebroek, ed., Da Costa's komplete dichtwerken (Amsterdam, 1870-1871) III, 105. Cursivering van mij, vdD. 
distinguish conservatism in politics, not because there was none, but because there was nothing else ${ }^{\prime 6}$. Toch is dit antwoord in dit verband uiteraard onbevredigend, want oppervlakkig. Nederlanders waren geen Papoeas, die tot diep in de twintigste eeuw hun primitieve tribalistische samenleving hebben bewaard, doch als volkomen geïntegreerde deelgenoten en dragers van de Europese cultuur, ja van de in politiek en socio-economisch opzicht meest gemoderniseerde West-Europese landengroep hebben zij met de grote vernieuwingen uit de achttiende en negentiende eeuw op hun manier eveneens kennis gemaakt.

En ook de reacties daarop, zoals het door Cecil bedoelde geprofileerde politieke conservatisme, waren voor Nederlanders geen onbekende dingen. Nolens opmerking bewijst om te beginnen, dat de term 'conservatief' ook hier bekend was en dat men er zich iets bij voorstelde.

De kernvraag is natuurlijk, wat wordt ermee bedoeld. De term duikt namelijk doorgaans in twee betekenissen in ons spraakgebruik op: in de ruime en meest algemene zin betekent conservatisme behoudsgezindheid en staat daarmee tegenover vernieuwingsdrang of progressiviteit. De vormen die behoudsgezindheid aanneemt zullen daarbij variëren al naar tijd en omstandigheden. De inhoud van dit conservatisme eveneens, alleen al omdat datgene wat conservatieven wensen te behouden omdat zij het bedreigd zien, totaal verschillend zal zijn in verschillende tijden en op verschillende plaatsen. En daarmee varieert ook vanzelf hun programma, hun redenatietrant, hun tactiek. Conservatisme treedt dus ook op waar men gewoon bepaalde posities wil beschermen tegen uitholling of afbraak. Het wordt in deze ruime zin een vrijwel onafscheidelijke eigenschap van elke figuur of groepering, die gezag uitoefent en macht in handen heeft. Conservatief in algemene zin zijn alle tegenstanders van politieke en sociale omwentelingen en verschuivingen; de leiders van een geëtableerd communistisch of socialistisch systeem evengoed als de leiders van een burgerlijk-kapitalistische maatschappij of de voorstanders van een monarchaal-aristocratisch bestel. De oude Stalin, de oude Mao evengoed als de oude Churchill of de oude Franco.

Maar daarnaast denkt de historicus bij conservatisme al gauw met Cecil en vooral in het kielzog van Karl Mannheim ${ }^{7}$ aan de grote tegenbeweging tegen Verlichting en Franse revolutie, die een zeer specifiek wereld- en maatschappijbeeld formuleerde: geënt op de feodaal-aristocratische samenleving en haar waardenstelsel, anti-liberalistisch en anti-natuurrechtelijk, organologisch en pragmatisch, kortom aan dat conservatisme, waar zich de meeste denkers en partijen in de loop van de negentiende eeuw op beroepen, die de naam conservatief dragen en dat in Edmund Burke gewoonlijk zijn geestelijke vader vereert. Zoals bekend heeft met name

6. Hugh Cecil, Conservatism (Londen, 1912).

7. Karl Mannheim, 'Das konservative Denken', Archiv für Sozialwissenschaft und Sozialpolitik, LVII (1927). 


\section{H. W. VON DER DUNK}

Mannheim dit specifieke historisch lokaliseerbare conservatisme onderscheiden van die boven bedoelde algemene behoudzucht, die hij traditionalisme noemt. Onder invloed bovenal van zijn fascinerende analyse is er een soort consensus ontstaan, waarbij conservatisme niet blinde starre behoudzucht is, maar afkeer van geforceerde veranderingen op basis van abstracte beginselen en rationalistische dogmata, afwijzing van of althans twijfel aan de vooruitgangsgedachte en het geloof in de perfectibiliteit van de mens en verwerping van de daarmee samenhangende gelijkheidsgedachte, doch in tegendeel het geloof in een fundamentele ongelijkheid van de mens; het geloof in een door de natuur of door God gegeven gezag; het geloof in de historie en de traditie als belangrijke richtingwijzers en in de ervaring. Dit conservatisme kent de ratio slechts beperkte bevoegdheden toe en ziet in de religie - gewoonlijk in de gevestigde godsdiensten - het onmisbare supplement op de rede en het domein, waar uitsluitend de laatste antwoorden gevonden kunnen worden. Conservatieven zien zichzelf niet als ideologen of theoretici maar als empiristen en pragmatici.

Of en in hoeverre terecht, is een probleem, dat in dit bestek niet nader behandeld kan worden. Evenmin wil ik hier Mannheims opvatting, die, hoe belangwekkend en penetrant ook, toch al te sterk gebonden is aan het bij uitstek Duits-romantische conservatisme van een Justus Möser en Adam Muller nader analyseren. De gebruikelijke gelijkstelling van conservatisme met deze negentiende-eeuwse reactie is zeer begrijpelijk, omdat de uitdaging van rationalisme en revolutie en de ondergang van de feodale samenleving alles wat in de maatschappij behoudsgezind was ingesteld, misschien meer dan ooit te voren tot het formuleren van een omvattende conservatieve filosofie dwong. Maar bovenal omdat de emancipatie van de burgerij en de opkomst van de parlementaire democratie de formatie van partijen meebrachten, waarbij de grondslagen van de samenleving en de toekomst aan een permanente discussie werden onderworpen. Tegenstanders van vernieuwing en omwentelingen werden zo doorlopend gedwongen hun standpunt te bepalen en plausibel te maken. Maar de scherpe scheiding tussen een onreflectief traditionalisme, dat van alle tijden is en een reflectief conservatisme, dat pas met die ondergang van het feodale bestel opkwam, is natuurlijk onhoudbaar. Ook vóór Burke en Möser hebben behoudsgezinde bewegingen zich terdege rekenschap moeten geven van hun wereldbeeld en dat van hun tegenstanders. Niemand kan in ernst volhouden dat alle verzet tegen innovatie van Cato tot Bolingbroke nog onreflectief was. Wil men dit niettemin traditionalisme blijven noemen, dan zal men in elk geval het onderscheid anders moeten formuleren. Elementen van het latere conservatisme afkeer van blauwdrukken en abstract redeneren, het geloof in natuurlijke ongelijkheid, de waarde, die aan ervaring en praktisch denken wordt toegekend - zijn ook eerder al aanwezig.

Aan de andere kant kan evenmin worden volgehouden dat sedert de negentiende 
eeuw elke behoudsgezinde figuur of beweging volledig beantwoordde aan de criteria, die voor dit nieuwe of bewust-reflectieve conservatisme werden opgesteld. Kortom, men ontkomt er niet aan om hoe dan ook bij de term conservatisme telkens een aanvullende kanttekening te maken: wil men het mét Cecil, Mannheim en de neo-conservatieve auteurs, zoals Mühlenfeld ${ }^{8}$, Mohler ${ }^{9}$, von Klemperer ${ }^{10}$, Russel Kirk $^{11}$, Viereck ${ }^{12}$ en Quintin Hogg ${ }^{13}$ laten slaan op de specifieke negentiende-eeuwse stroming en geesteshouding, dan is men gedwongen om voor alle andere vormen van conservatisme - vóór 1789, binnen het liberale kamp, binnen het socialistische, binnen het communistische - een andere term te bedenken, die duidelijk maakt, dat we hier met behoudsgezindheid te doen hebben. Wil men de term in zijn eerste algemene betekenis hanteren, dan moet men het specifieke negentiende-eeuwse conservatisme in de lijn van Burke als zodanig nader aangeven. Aangezien het gangbare spraakgebruik het woord al lang voor elke vorm van behoudsgezindheid bezigt, lijkt mij de tweede optie het meest reëel.

Conservatisme als zodanig is dus van alle tijden en we vinden buiten de partijen, die in de negentiende en twintigste eeuw quasi officieel dat etiket dragen nog tal van andere vormen en soorten. En daarmee zijn we terug bij Nolens opmerking uit 1917 en bij Heldrings klacht uit 1973. Nederland, een land waar niemand in onze eeuw nog conservatief wilde heten en waar een geprofileerde en gefundeerde conservatieve beweging ontbroken zou hebben, terwijl het ouderwetse, naar verhouding vrij statische en traditiebepaalde bestel vóór 1940 toch duidelijk de aanwezigheid van zeer sterke conservatieve krachten (in de algemene betekenis van het woord!) verraadt.

Wanneer de term 'conservatief' hier in de politiek zo'n negatieve bijsmaak had, dan werd en wordt daarbij ergo aan een zeer speciaal conservatisme gedacht. De conservatieven uit de vorige eeuw, de enige partij die inderdaad die naam droeg, de oude anti-Thorbeckeanen, waren roem- en geruisloos nog voor de eeuwwisseling uit de partijpolitieke staalkaart verdwenen. Een deel was bij de oudliberalen, een deel bij de antirevolutionairen terechtgekomen en de diepste oorzaak van die ontbinding moet gezocht worden in het gebrek aan visie, het gebrek aan een eigen vruchtbare en gefundeerde filosofie, die tot politiek handelen vermocht te inspireren. Vandaar dat conservatisme in politicis een synoniem werd en gebleven is voor starre enge behoudzucht. Vanwaar nu echter dat gebrek aan visie, aan vrucht-

8. Hans Mühlenfeld, Politik ohne Wunschbilder (München 1952).

9. Arnim Mohler, Die konservative Revolution in Deutschland (Stuttgart, 1950).

10. Klemens von Klemperer, Konservative Bewegungen zwischen Kaiserreich und Nationalsozialismus (Wenen, 1961).

11. Russel Kirk, The Conservative Mind (London, 1964).

12. Peter Viereck, Conservatism revisited (New York-Londen, 1949).

13. Quintin Hogg, The Case for Conservatism (Londen, 1947). 
bare alternatieven, die nu eenmaal altijd de onmisbare legitimatie zijn voor een beweging of partij?

Voorwaarde voor het ontstaan van het negentiende-eeuwse geprofileerde conservatisme als filosofische en politieke stroming was de uitdaging geweest van Verlichting, revolutie en liberalisme. Het conservatisme had tegenover de rationalistische maatschappijvisie en de vooruitgangsgedachte van de liberale burgerij de 'natuurlijke' ordening gesteld, die met een feodaal-agrarisch verleden werd geïdentificeerd.

In Nederland echter ontbrak dat verleden, ontbrak een sterke feodaal-agrarische traditie, die in Engeland, Frankrijk, Duitsland en vele andere landen als de grote levende inspiratiebron van het conservatisme fungeerde, waarachter zich dikwijls verschillende groeperingen, verschillend ook in sociaal opzicht, konden verenigen. De oorsprong van de Nederlandse staat was revolutionair en de Republiek had haar stempel ontvangen van het stedelijke element. Ook het orangisme had immers voor een belangrijk deel een stedelijke basis in het calvinistische volk, al vinden we hier óók dat andere element, de feodale landadel. Die was er echter nooit in geslaagd zich van het orangisme meester te maken, dat wil zeggen, het orangisme tot een instrument van zijn feodaal-aristocratische tradities en concepties om te smeden. Dat is des te opmerkelijker omdat de Oranjes zelf met hun monarchale ambities allerminst afkerig waren van de feodaal-aristocratische ordening, die overal in Europa de voedingsbodem van de moderne monarchie was geweest. Doch ook de stadhouders konden de calvinistisch-stedelijke component onder hun aanhang nooit verwaarlozen. Wanneer men in de Oranjes dan al pseudo-monarchen bij de gratie Gods vermocht te zien, dan kon ook de vurigste orangist nooit uitvlakken, dat de stadhouders aan het hoofd van een staat stonden, die een stedelijk-commerciële basis had. Men kon de Hollandse regenten, de staatsgezinden, als een stel hinderlijke partij- en factiegenoten afschilderen, men kon nooit de rol van Holland en de stedelijke traditie elimineren. Juist de traditionele achterban van Oranje, de calvinisten konden dat niet, omdat net het calvinisme (anders dan het lutheranisme) een stedelijke basis had. En in verband weer daarmee een revolutionaire oorsprong. Tegenover de ideeën van 1789 en tegenover het liberalisme, kon het conservatisme in Nederland, anders dan het continentale of het Engelse à -la-Burke, dus alleen teruggrijpen óf op het pseudo-monarchale orangisme óf op de aristocratische regententraditie, doch in beide gevallen betrof het een verleden dat op grond van zijn commercieel-stedelijk karakter een te smalle basis bood voor een omvattende fundamentele tegenaanval op het liberaal-burgerlijke maatschappijbeeld van de negentiende eeuw. Dit maatschappijbeeld betekende voor Nederland immers een minder scherpe breuk met zijn verleden, dan voor de andere landen. De hier gesignaleerde burgerlijk-stedelijk oorsprong van de Nederlandse staat is natuurlijk al lang bekend; juist in de buitenlandse geschiedschrijving. Bij ons 
heeft vooral Huizinga de betekenis ervan voor de Nederlandse samenleving onderstreept, als een constituerende factor voor 'Nederlands geestesmerk' ${ }^{14}$. In een brief aan Nijhoff van 1927 schreef hij: 'Bourgeois zijn wij allen, met name in ons brave vaderland, van den baron tot den proletarier en van den dichter tot den notaris.. . ${ }^{15}$.

Uiteraard stuitten de revolutionaire beginselen hier evengoed op verzet als elders. Maar het opmerkelijke is dat dit verzet, bij gebrek aan een sterke feodaal-agrarische traditie, zo verdeeld bleef. Niet dat er geen conservatisme in Nederland was, maar dat dit conservatisme niet tot een homogene beweging vermocht uit te groeien, is dus het specifieke. Willem I kon, juist als exponent van de anti-liberale monarchale tendens van het orangisme, niet of slechts met veel voorbehoud teruggrijpen op de Republiek, waarin die tendens zich immers nooit volledig had kunnen realiseren. Hij zocht het daarom in een synthese van orangisme en verlicht absolutisme en distantieerde zich van de traditionele Oranjeaanhang. De notabelenkaste zij bestond bovenal uit adellijke en oud-regentenfamilies - die onder zijn bewind de dienst uitmaakte, was daarom wel anti-liberaal en anti-revolutionair (in de algemene, niet de speciaal-Nederlandse betekenis van het woord!), maar zij vormde een voorbeeld van fantasieloos behoudsconservatisme, omdat de inspiratie van een verleden met een beheersende aristocratisch-feodale traditie ontbrak.

Het ontbreken van die brede historische basis doet zich ook in het denken en de concepties van een figuur als Van Hogendorp zo schrijnend gevoelen; Van Hogendorp, die zich weliswaar keerde tegen het centralisme en het verlicht-absolutistische regime van Willem I, maar dit in feite juist deed vanuit een conservatieve positie, ook al is hij herhaaldelijk met het liberalisme in verband gebracht. Wat hij echter op het oog had was herstel van de Republiek, weliswaar niet terugkeer zonder meer maar toch een veel sterkere oriëntatie op haar tradities en instellingen dan de koning wenselijk vond. Van Hogendorps gedecentraliseerde standenstaat was bedoeld als rem op de centralistische monarchie, maar natuurlijk evenzeer als rem op alle revolutionair-democratische stromingen. Die staat was typisch conservatief als nieuwe oplage van de oude Republiek. Dat hij niettemin ook liberale of beter pseudo-liberale trekken vertoonde, ligt (alweer!) aan het karakter van die Republiek, aan haar burgerlijk-stedelijke signatuur. Zo kon Van Hogendorp door zijn streven om aan te knopen bij de commerciële vrijhandelstraditie van de Republiek en bovenal bij haar anti-centralistische structuur quasi liberaal lijken en toch traditionalist en conservatief zijn ${ }^{16}$.

14. Huizinga, Nederlands geestesmerk, VW, VII, 279.

15. Brief van 18-12-1927. Vergelijk Maatstaf(1954-1955) 206.

16. Naast C. H. E. de Wit, De strijd tussen aristocratie en democratie in Nederland (Heerlen, 1965) heb ik inzage kunnen nemen, wat Hogendorp aangaat, in een ongepubliceerde doctoraalscriptie van H. van der Hoeven, 'Gijsbert Karel van Hogendorp, conservatief of liberaal?' (Utrecht, 1972). 
Naast het behoudsconservatisme van de dragende notabelenkaste en het herstelconservatisme van een Van Hogendorp vinden we in de eerste helft van de eeuw nog een derde conservatieve reactie, uiteindelijk de belangrijkste en meest fundamentele in het Réveil. De verwerping van alle natuurrechtelijke beginselen en van het vooruitgangsgeloof, het teruggrijpen op een geheroïseerd christelijk-calvinistisch verleden, het pessimistische mensbeeld onthullen de misschien zuiverste Nederlandse variant van het negentiende-eeuwse conservatisme. Maar een Nederlandse variant inderdaad! Bij gebrek aan de feodaal-aristocratische traditie komt het zwaartepunt te liggen op de christelijk-calvinistische beginselen, zij het dat de invloed van het buitenlandse conservatieve denken eveneens aanwezig is. Op een eiland bevonden zich de Nederlandse conservatieven uiteraard niet. En toch kan men zeggen, dat de bijbel hier het equivalent werd voor de feodale standenstaat, waar alle conservatieven en anti-modernisten zich aan vast hielden, wilden zij met een vruchtbaar alternatief komen.

Het opmerkelijke is dat we wel herhaaldelijk aanzetten vinden tot een conservatieve beweging zoals elders; een conservatisme dus, dat in het christendom weliswaar een waardevolle maatschappij-conserverende bondgenoot ziet, maar dat toch inwezen al pagaan is, door de wol van Verlichting, rationalisme en secularisatie onherroepelijk geverfd. Rond 1860 duikt het op bij figuren als Wintgens en Lion ${ }^{17}$. In het denken van Multatuli niet minder. Doch even opmerkelijk als die aanzet zelf is het falen om vanuit een pagane basis tot een inspirerend alternatief voor de liberale maatschappij en wereldopvatting en voor de liberale staat te komen. Het bleef bij kleine geïsoleerde groepjes of zuivere individualisten. De zogeheten conservatieve partij, die zich in de jaren zestig formeerde, rekruteerde zijn aanhangers deels uit de oude ngtabelenkaste, de behoudsconservatieyen uit de tijd van Willem I, die zich tegen de grondwet van 1848 hadden verzet, deels uit wat wel de conservatief-liberalen zijn genoemd: een middengroepering in die zin, dat zij zichzelf veelal als gematigd liberaal beschouwden, het regime van Willem I hadden bekritiseerd en hervormingen hadden voorgestaan, doch Thorbeckes grondwet ook weer rijkelijk veel van het goede hadden gevonden ${ }^{18}$. De Indische kwestie, die na zestig de kamer bezig hield, dreef nu deze liberaal- of gematigd-conservatieven en de oude conservatieven in eikaars armen, omdat beide groepen bang waren, dat de liberalen het koloniale bezit te gronde zouden richten. Doch deze conserva-

17. In de doctoraalscripties van L. M. G. P. Smeets, 'Isaak Jacob Lion (1821-1873)' (Utrecht, 1966) en C. W. Korevaar, 'De conservatieve partij in Nederland 1860-1865' (Utrecht, 1963), vond ik nadere gegevens over Wintgens en Lion.

18. Vergelijk J. C. Boogman, 'De Britse gezant Lord Napier over de Nederlandse volksvertegenwoordiging (in 1860)', Bijdragen en Mededelingen van het Historisch Genootschap, LXXI (1957) 186. Voorts idem, 'Achtergronden en algemene tendenties van het buitenlands beleid van Nederland en België in het midden van de 19e eeuw', ibidem, LXXVI (1962) 43 en Th. van Tijn, 'Op de drempel van een nieuwe tijd', in: Algemene Geschiedenis der Nederlanden (12 dln; Utrecht 19491958) X, 302. 
tieve partij werd daarmee nog lang niet de exponent van dat boven genoemde pagane conservatisme naar buitenlands model. Steunend op de deels commerciële bovenlagen wilde zij te zeer de status quo handhaven en kon zo niet uitgroeien tot een brede beweging met een geprofileerde anti-liberale conceptie, die aan grotere volksgroepen appelleerde. Slechts het protestantisme vermocht de feodaalagrarische traditie te vervangen en een geïnspireerd anti-liberaal conservatisme te ontwikkelen.

Het Réveil was nog geïsoleerd gebleven en ook Groen had de conservatieve regeringskaste en het protestantse kiezersvolk niet naar elkaar toe gebracht. Hij wilde dat ook nauwelijks, omdat hij zeer goed het onderscheid zag tussen het steriele behoudsconservatisme van de notabelen en zijn eigen op het grote calvinistische verleden geïnspireerde opvattingen. Vooruitlopend op de latere discussie onderscheidde hij al een herstel- en een behoudsconservatisme. Het eerste was er op uit om 'refaire Ie passé', het laatste wilde, bang voor de consequenties van het revolutionaire beginsel, slechts weerstand bieden aan de gevolgen, echter 'en persistant dans ses erreurs ${ }^{19}$. Dat sloeg uiteraard op de conservatieven, waarvan Groen zich altijd nadrukkelijk distantieerde omdat zij in zijn ogen verkapte liberalen waren. Hij toonde daarmee een scherp oog voor de tweeslachtige oorsprong van het koninkrijk van Willem I en zijn nieuwe elite, die we zoeven hebben gesignaleerd. Dat koninkrijk was immers een poging om wél de monarchale centralistische tendens, maar niet het calvinisme uit de orangistische traditie over te nemen. In plaats daarvan werd de rationalistische Franse en dus in wezen revolutionaire staatsopvatting geadopteerd. Het verzet van de notabelenkaste tegen de liberale staat miste daardoor de historische en sociale diepgang. Wat Groen niet door had en moeilijk door kon hebben, was, dat zijn eigen conservatisme en anti-liberalisme, al bezat het wél die historische dimensie, in verband met de al herhaaldelijk hier ter sprake gekomen stedelijk-revolutionaire basis van het calvinisme en van de oude Republiek ook nooit zo fundamenteel met het liberalisme zou kunnen botsen als het conservatisme, dat op een feodaal-agrarische basis terug kon vallen.

Het is een gemeenplaats geworden om Groen, de theoloog en denker te contrasteren met zijn opvolger Kuyper, de volksmenner en politicus, die het protestantse kiezersvolk in beweging wist te brengen. Het verschil kan echter niet uitsluitend worden teruggebracht tot een andere persoonlijke aanleg. Toen Kuyper zich roerde, in de jaren zeventig, kón het kiezersvolk in beweging komen omdat het door de maatschappelijke en economische verschuivingen rijp was voor mobilisatie, omdat toen pas de vrij statische samenleving in beweging kwam.

De modernisatie valt volgens recente opvattingen in de tijd na 1880, ja na 1890 .

19. G. Groen van Prinsterer, Le parti antirevolutionaire et confessionel dans l'église réformée des Pays Bas (Amsterdam, 1860) 76. Ik vond dit citaat in de genoemde doctoraalscriptie van Smeets. Zie noot 17 . 
En op cultureel vlak, in de literatuur - ook een thermometer voor de nationale lichaamstemperatuur - wordt het eveneens pas waarlijk interessant in de jaren tachtig. Rond zeventig klaagt Van Vloten nog vrijwel elk nummer van de Levens$b_{\text {bode }}{ }^{20}$ vol over de Jan Saliegeest, en niet als enige. Het liberale stelsel was in Nederland opgericht in een samenleving, die nog niet door de industrialisatie in beweging was gebracht. Wanneer de revolutionair-burgerlijke oorsprong van de $\mathrm{Ne}$ derlandse staat verklaart, waarom het feodaal-agrarisch georiënteerde conservatisme hier niet vermocht te aarden zoals in die landen, waar naar een landelijkaristocratisch inspiratiebeeld kon worden terugverwezen, dan verklaart die oorsprong tevens dat het liberalisme een minder revolutionaire uitdaging leek. Het kon zich namenlijk als erfgenaam van de Loevesteinse richting presenteren, dus eveneens als een historisch-traditionalistische stroming. Een trek, die dan vergroot werd door de genoemde omstandigheid, dat de liberale staat in een vrij statische pre-industriële samenleving kon worden opgericht. De oude conservatieven, die die naam als enigen officieel in de geschiedenis dragen, de anti-Thorbeckeanen, weken voetje voor voetje terug. Vandaar niet minder de versplintering van het conservatisme ; het isolement van de anti-liberale Réveil-groep of van de groot-protestantse beweging rond Mulder.

De grote uitdaging om de conservatieven of anti-modernisten van diverse pluimage te verenigen, kwam pas later. Ongetwijfeld vormt die afwezigheid van de grote onrust in de diepte, in de bredere volkslagen tijdens het eerste driekwart van de eeuw een belangrijke verklaring, waarom de discussie tussen liberalen en antiliberalen in deze decennia zo weinig substantieel, zo vergeestelijkt en subtiel aandoet. De andere verklaring echter blijft het verleden, dat de tegenstanders hier als gemeenzaam erfgoed bezaten. Toen de grote deining echter op gang kwam, toen grotere groepen van de bevolking de vertrouwde grond onder hun voeten voelden trillen, was het parlementair-liberale stelsel gevestigd. Het verzet van de oude conservatieve notabelenkaste was gebroken. En dat bracht met zich mee, dat de liberalen voortaan verdedigers van een bestaand arrangement werden. Het is een algemeen Europees verschijnsel. Het liberalisme wordt in de jaren zeventig en tachtig behoudend. Maar uiteraard blijft dit nieuwe liberaal-conservatisme iets anders dan het feodaal-agrarische.

Het liberalisme bestond (zoals ieder-isme) uit verschillende componenten, die elkaar aanvulden en steunden zolang de middenklassen nog voor hun invloed moesten vechten, maar die met elkaar in botsing kwamen zodra enkele belangrijke desiderata, zoals een constitutioneel bestel, een sterk parlement en census-kiesrecht waren verwezenlijkt. Het blijft altijd een privilege van een onmondige, zich onderdrukt voelende groep, dat zij de eigen emancipatiestrijd kan identificeren met de emancipatie van allen die in het donker wandelen. Het Europese liberalisme wortel-

20. J. van Vloten, ed., De Levensbode (Zutphen-Deventer-Haarlem, 1865-1877). 
de in het optimistische toekomstbeeld van de Verlichting: het geloof in de perfectibiliteit van de mens. Natuurlijk bleef dit beeld vaag zoals elk toekomstvisioen. De toekomst ligt altijd voor ons als één maagdelijk geheel. In het heden pas openbaren zich de tegenstrijdigheden. Globaal kwam het erop neer, dat er steeds meer liberale beschaafde burgers zouden zijn. Uit de sociale droesem in de diepte zouden de bekwame energieke elementen telkens opnieuw op kunnen stijgen, in vrije zelfontplooiing. Deze humaan-democratische component harmonieerde oorspronkelijk uitstekend met een individualistisch prestatiedenken en met een uitgesproken anti-etatisme. De staat was immers aanvankelijk nog de standenstaat van kroon en altaar en een heel netwerk van schotten, kasten- of gildenreglementen; een sta-inde-weg voor de emancipatie. Maar toen de liberalen deze staat hadden gesloopt, toen de bovenlaag van de burgers inderdaad invloed had gekregen, kwam de humaan-democratische component in botsing met het individualistische prestatiedenken en met de inmiddels verworven invloed.

Het vraagstuk, waar de liberalen in heel Europa zich na het midden van de eeuw steeds nadrukkelijker voor gesteld zagen, luidde: hoe de vooruitgang en de democratische ontwikkeling (dat wil zeggen: de emancipatie van allen, die nog geen deel hadden aan de zegeningen van de moderne beschaving) te bevorderen, zonder de na een taaie strijd veroverde politieke en economische posities prijs te moeten geven? In het oude liberale toekomstvisioen had immers het proletariaat als factor ontbroken. De consequenties van de industrialisatie waren er nog niet in verdisconteerd. Maar de liberale staat, zoals die inmiddels was ontstaan, zat met dit proletariaat in zijn maag. Men kon het niet missen en men kon het evenmin in zijn troosteloosheid laten voortvegeteren. Het individualistische prestatiedenken was humaan geweest in een tijd dat op één fabrieksschoorsteen nog honderd kerktorens kwamen. Het werd inhumaan, toen die verhouding begon om te keren. Dat had het socialisme begrepen. Het leerde dan ook dat voor een vrije ontplooiing van de autonome persoonlijkheid - oorspronkelijk ook het ideaal van de socialisten - allereerst een gelijke maatschappeiujke startpositie was vereist. Het socialisme nam zo de humaan-democratische traditie van het liberalisme over. Dit conflict tussen de oorspronkelijk harmoniserende componenten plaatste het liberalisme voor een dilemma, met het gevolg dat de liberale theorievorming stagneerde en tenslotte zo wezenloos en steriel werd. De liberalen trachtten alsmaar een methode te vinden om door te lopen zonder de standplaats op te geven. In de praktijk betekende dat ook in Nederland een voortdurende afbrokkeling en corrosie. Rond zeventig vinden we al de behoudende Thorbeckeanen tegenover de jongliberalen, die het kiesrecht willen uitbreiden. Twintig jaar later zijn de liberalen nog meer in het defensief gedrongen. Dan zijn de jongliberalen van anno zeventig (zoals Sam van Houten) oudliberalen geworden; huiverig voor de laatste consequentie van algemeen kiesrecht vinden ze een nieuwe generatie jongliberalen tegenover zich. 
Men moet het Nederlandse liberalisme de eer laten, dat het de gymnastische oefening om door te lopen en toch te blijven staan heroïsch letterlijk tot scheurens toe heeft trachten te volbrengen. Het waren liberale kabinetten, die - zo zeer in strijd met het liberale anti-etatisme, maar zo geheel in overeenstemming met de humaan-democratische traditie - een moderne sociale politiek inaugureerden. Telkens scheidt zich zo een progressieve vleugel af, die bereid is ballast over boord te gooien, nieuwe lagen van het volk in het politieke spel te betrekken, waarbij de radikalen en later de Vrijzinnig Democratische Bond soms al zo ver opschuiven, dat hun brilleglazen beslagen raken door de adem van de socialisten. Maar telkens ook blijven groepen liberalen achter, die men nu als handhavers van de status quo kan bestempelen: als conservatieven in de algemene zin. Dat zij zelf dat niet altijd door hebben, is een andere zaak. Zij contrasteren zelfs nog in het Interbellum hun liberalisme als een linkse ideologie met het confessionele denken. Zij blijven zichzelf zien als progressieven en aanhangers van de vooruitgangsgedachte. Maar het is een belegen progressivisme van gisteren; van de negentiende eeuw. Door de industrialisatie en door de massificatie van de moderne samenleving was het oude liberale toekomstvisioen onverbiddelijk naar het rijk van de utopieën verhuisd. Verouderde toekomstvisioenen zijn psychologisch echter even moeilijk los te laten als verouderde mythen omtrent het verleden. Zij fungeren als moreel alibi voor degenen, die op grond ervan reële macht en invloed hebben verworven.

Ondanks de uitzonderlijke elasticiteit en de sterke en lange doorwerking van die humaan-democratische traditie kon het Nederlandse liberalisme echter niet ontkomen aan het noodlot dat het de ideologie was geweest van de beschaafde klassen, van een geëtableerde laag. En dat had tot gevolg, dat toen de anti-liberale tegenbeweging - een conservatisme in de zin van een positieve maatschappijfilosofie eindelijk goed en wel na 1870 op gang kwam, deze tegenbeweging juist ook democratisch-emancipatorische elementen in zijn rugzak had. De antirevolutionaire maatschappijconceptie vertoont nu ontegenzeggelijk een aantal trekken, die de stelling rechtvaardigen, dat we hier de Nederlandse variant van het negentiendeeeuwse conservatisme voor ons hebben, evenals zijn voorloper het Réveil: de beginselen van 1789 en de leer van de volkssouvereiniteit worden vierkant afgewezen. Het liberalisme wordt bestreden en de argumenten evenals de typering ervan als atomistisch en mechanistisch zijn bij Kuyper en de antirevolutionairen dezelfden als elders in het conservatieve kamp. Tegenover de liberaal-democratische staat, het 'demo-liberalisme' zoals de betiteling zou heten, plaatst Kuyper een organisch geordende standen-democratie, gebaseerd op de ingenieuze gedachte van de souvereiniteit in eigen $\mathrm{kring}^{21}$. Dat achter dit alles een duidelijk anti-rationalisme en anti-modernisme schuil gaat, behoeft geen betoog.

21. Vergelijk J. van Weringh, Het maatschappijbeeld van Abraham Kuyper (Assen, 1967). Dit boek heeft niettegenstaande de simplistische en ook onhistorische aanpak de verdienste een onder- 
Men heeft in Kuypers anti-revolutionaire theorie onduidelijke plekken en halfslachtigheden aangewezen en men heeft er ook wel aan herinnerd, dat hij tevens iets had geërfd van het liberale vooruitgangsoptimisme, dat heel het geestelijk klimaat van de negentiende eeuw zo had doortrokken ${ }^{22}$. Ik wil dat niet tegenspreken. Kuyper kon al geen zwartgallige pessimist of onheilsprofeet zijn, omdat geen politicus of staatsman zijn energie aan een zaak zal wijden, die hij verloren acht. Als realist ging hij bovendien vanzelfsprekend uit van wat de liberalen in Nederland nu eenmaal tot stand hadden gebracht en de onduidelijkheden en tegenstrijdigheden in zijn filosofie waren in zekere zin de voorwaarde voor zijn politieke invloed en successen. De geïsoleerde Groen, die nog veel meer als profeet in de windstilte van een traditionalistisch-rustige samenleving riep, kon juist daarom als theoloog en theoreticus consequenter zijn dan zijn opvolger. Kuyper geloofde in de toekomst. Maar dat doen de conservatieven elders ook in dié zin, dat zij streven naar een ordening, waarbij de oude waarden en samenlevingsvormen weer opnieuw tot hun recht zullen komen. Het conservatisme gelooft in de herhaling. Kuypers beweging was een herstelbeweging: herstel van Nederland als protestants-calvinistische natie, die door het liberalisme, zoals hij het zag, op een dwaalweg was gebracht. Als practicus en pragmaticus was Kuyper vanzelf een schipperaar; in tegenstelling bijvoorbeeld tot Hoedemaker, die een veel radikaler en zuiverder herstel eiste, maar die dan ook geen effectieve antirevolutionaire partij van de grond kreeg en slechts in kleine protestantse ultrapartijtjes, zoals de Hervormd Gereformeerde Staatspartij later een mondstuk zou vinden ${ }^{23}$. Het gemeenschappelijke mag ons overigens niet de ogen doen sluiten voor datgene wat het Nederlandse conservatisme opnieuw onderscheidt van andere Europese conservatieve bewegingen in deze tijd. De calvinistische traditie bezat de nodige democratische ingrediënten; alweer in verband met de revolutionaire oorsprong. Kuyper kon zich dan ook democratisch én conservatief tegelijkertijd opstellen, als voorvechter van het volk tegen de deftige liberale burgerij én als voorvechter van een traditionalistischchristelijke samenleving tegenover een modern-paganistische staat. Het Nederlandse katholicisme verkeerde in een soortgelijke positie, zij het na een totaal andere voorgeschiedenis. Katholieken en calvinisten vonden elkaar zo in hun emancipatiestrijd en als voorstanders van een anti-liberale conservatief-christelijke democratie, hoe zeer zij verder ook tegenover elkaar kwamen te staan.

zoek naar het geheel van Kuypers staats- en maatschappijopvatting te zijn. Voor een kritische bespreking van Van Weringhs boek zie A. van der Woude in Bijdragen en Mededelingen betreffende de Geschiedenis der Nederlanden, LXXXIV (1968) 179.

22. Vergelijk E. H. Kossmann, 'De groei van de anti-revolutionaire partij', in: Algemene Geschiedenis der Nederlanden, XI, 1.

23. Wat de denkbeelden van Hoedemaker en zijn invloed op de Hervormd Gereformeerde Staatspartij en ds. Lingbeek betreft, heb ik een en ander geleerd uit een doctoraalscriptie van B. Timmerman, 'De Hervormd Gereformeerde Staatspartij' (Utrecht, 1968). 


\section{H. W. VON DER DUNK}

De modernisatie in Nederland leidde met dit al tot een reconfessionalisering van de politiek. De verbinding van christelijk-sociale ideeën met een conservatief waardenpatroon, van conservatisme en democratie was trouwens geen Nederlandse specialiteit. Een vergelijking met de vernieuwingsbeweging bij de Engelse Tories rond de eeuwwisseling dringt zich op, met Randolph Churchills 'Torydemocracy'24. Maar de sterk vertraagde industrialisatie, sterk vertraagd althans vergeleken met Engeland, verklaart misschien gedeeltelijk waarom die reconfessionalisering hier zo'n omvang en diepgang bereikte. Nog voordat de liberalen het licht van hun beschaving en tolerantie tot de lagere volksklassen hadden kunnen uitdragen, nog voordat de socialisten een grote ontkerstende volksmassa aantroffen om het nieuwe evangelie van klassestrijd en arbeidersstaat te prediken, mobiliseerden de protestantse en katholieke voormannen met succes die volksmassa en eisten democratisering en emancipatie in naam van een conservatief-christelijk inspiratiebeeld. Het gezag van de kerk van beiderlei confessie was nog krachtig genoeg om een ideologie geloofwaardig te maken, die leerde dat Nederland bovenal een christelijke natie was en die in het evangelie de laatste antwoorden ook op de problemen van de moderne wereld zag.

Een factor, die naast de eerder genoemde factoren van sociale- en economische aard - die vandaag wel eens wat al te vanzelfsprekend de eerste plaats op het prioriteitenlijstje van de historicus innemen - niet vergeten mag worden, is de neutrale positie van Nederland: een kleine staat, rijk dankzij een kolossaal koloniaal bezit, angstvallig en meer dan een eeuw lang met succes onzijdig, levend aan de rand van het moderne Europa. Het voorbeeld van Zwitserland dat deze status nog veel langer wist te continueren, leert hoe belangrijk een lange afzijdigheid van internationale conflicten is voor de groei van een traditie-gebonden conservatief klimaat. De modieuze leer van het 'Primat der Innenpolitik' is dan ook uiterst discutabel.

De beëindiging van de schoolstrijd, de invoering van het algemeen kiesrecht en daarmee van de volledige democratie in formele zin, schiepen na 1920 een nieuwe situatie. Het liberalisme, innerlijk verscheurd tussen de behoudende en de progressieve krachten, had weinig politieke stootkracht meer. Treub had trouwens al in 1891 de liberale partij gekarakteriseerd als 'een oude jongejuffrouw, in wie, hoe lang je haar ook aait, geen leven meer is te krijgen' en naar verluidt was Treub op dit gebied niet geheel onbedreven ${ }^{25}$. De confessionelen hadden hun emancipatorische beloften en programmas voor het grootste deel ingelost. Evengoed als de rechtervleugel van de liberalen waren zij voortaan bovenal geïnteresseerd in een behoud van de wezenlijke sociale en economische verhoudingen. Meer en meer zagen zij in het socialisme daarom de grote dreiging. De periode van het Interbellum, waarin 'conservatief' volgens Nolens zo'n vies woord was, wordt zo geken-

24. R. Blake, The Conservative Party from Peel to Churchill (Londen, 1970).

25. Vergelijk H. J. L. Vonhoff, De zindelijke burgerheren (Baarn, 1965). 
merkt door de vaste wil van de grote partijen om Nederland niet ten prooi te laten vallen aan 'de goden van de tijd'. De periode staat in het teken van de afbraak van Kuypers antithese, waarbij Colijn vooral als de executant optrad. Wanneer ik dat zo stel, dan wil dat uiteraard niet zeggen, dat men aan confessionele of liberale zijde van begin af aan in die liquidatie van de oude controverse 'de' grote taak zag, die nu gemeenschappelijk aangepakt diende te worden. Zowel in het ene als in het andere kamp had de traditie van de antithese diepe sporen achtergelaten en velen vervielen telkens weer in het vertrouwde denkspoor. Tegelijkertijd werd de oeroude tegenstelling in het confessionele kamp tussen Rome en Dordt weer zichtbaar, nu de katholieken tot een volwaardige partner van de coalitie waren uitgegroeid. Juist de oude Kuyper, merkwaardig genoeg, toonde zich na 1918 een tegenstander van een verder samen optrekken met de katholieken ${ }^{26}$. De coalitie moest duidelijk onder protestantse leiding blijven staan. En de protestantse ultras, vergaard in de Staatkundig Gereformeerde Partij en de Hervormd Gereformeerde Staatspartij droegen nog authentieke zeventiende-eeuwse brilletjes en zagen in Rome onveranderlijk het grote gevaar. Dat desondanks de antithese afbrokkelde en vervangen werd door een christelijk-liberale synthese bewijst de diepere half onbewuste consensus, waarbij zich confessionelen én liberalen als broeders en hoeders van de nationale traditie gingen beschouwen in een wereld, die in hun ogen volledig op drift begon te raken.

De confessionelen worden liberaler wat hun sociale en economische instelling betreft. Met name geldt dat voor de protestantse partijen. Liberaler, dat wil dan in het Interbellum zeggen: afkerig van toenemende overheidsbemoeiing en van sociale maatregelen; op de bres voor het vrije ondernemerdom. Bruins Slot is in zijn memoires ... en $i k$ was gelukkig ${ }^{27}$ in dit opzicht minder gelukkig met de rol van Colijn, die de christelijk-sociale traditie van Kuyper had verlaten en die zich zo duidelijk een man van het groot-kapitaal had getoond. Deze liberale beginselen werkten ook door in het bezuinigings- en aanpassingsbeleid, dat de regering Colijn in de crisisjaren voerde. De kritiek op dat beleid is recentelijk door P. W. Klein aangevochten, die er op wijst dat ten eerste de mogelijkheden voor de regering zeer beperkt waren omdat de achterliggende structuur van de Nederlandse industrie een effectieve crisisbestrijding veel meer bemoeilijkte dan bijvoorbeeld in Enge$\operatorname{land}^{28}$. Bovendien stelt Klein, dat juist het aanpassingsbeleid, alle mooie bezuinigingsvoornemens en sluitende begrotings-rethoriek ten spijt, terdege tot actieve regeringssteun voerde en dat in feite de uitgaven telkens toenamen. Maar ook Klein ontkent niet, dat hier gewoon sprake was van een overweldigende druk der

26. Zie G. Puchinger, Colijn en het einde van de coalitie (Kampen, 1969).

27. J. A. H. J. S. Bruins Slot, ...en ik was gelukkig (2e dr.; Baarn, 1972).

28. P. W. Klein, 'Depressie en beleid tijdens de jaren dertig', in J. van Herwaarden, ed., Lof der Historie (Rotterdam, 1973) 289 vlg. 


\section{H. W. VON DER DUNK}

omstandigheden en dat de regering aarzelend, zo niet tegenstribbelend, telkens voor die druk tot actiever ingrijpen zwichtte. De op zichzelf zeer interessante vraag of een eerdere devaluatie van de gulden, bijvoorbeeld in 1931 al, tot wezenlijke verlichting van de crisis zou hebben bijgedragen en veel algemener de vraag of er wel veel zinvolle alternatieven waren; of met andere woorden een actief sociaal beleid of een aanpak à la Keynes in de Nederlandse verhoudingen destijds mogelijk en wenselijk was, is hier echter niet aan de orde ${ }^{29}$. Waar het mij om gaat, is de verregaande consensus wat het economische en sociale beleid betreft tussen de protestantse confessionelen (de katholieken namen een ietwat progressiever standpunt in) en de liberalen, dat in de samenwerking tussen Colijn en de zelfs zeer links-liberale Oud verpersoonlijkt werd; onverschillig wat er van terecht kwam.

Omgekeerd toonden de liberalen zich christelijk in die zin, dat men in het liberale kamp en wel bij de behoudende Staatspartij evengoed als bij de vooruitstrevende Vrijzinnig-Democratische Bond steeds nadrukkelijker de waarden en het belang van de alomvattende christelijke cultuur en ethiek hoort prijzen en beklemtonen tegenover het moderne nihilisme of de verafschuwde leer van het atheïstische communisme ${ }^{30}$.

Het doorlezen van de officiële partijprogrammas uit de jaren dertig vormt soms verrassende en dikwijls ook amusabele lectuur, waarbij men zich niet aan de indruk kan onttrekken, dat voor CHU, ARP en Liberale Staatspartij de tijd stilstond $^{31}$. Nu kleeft aan vele partijprogrammas natuurlijk in verband met de onvermijdelijke fraseologie een luchtje van luchtledigheid. Maar ook hier weer gaat het om de consensus op wezenlijke punten. Verschillen zijn er uiteraard ook, doch die liggen nu juist meer in de theoretische, bijna zou ik willen zeggen, rituele sfeer. Het belangrijkste verschil blijft, dat de confessionelen het beginsel van de volks-

29. Klein ontkent dit in zijn zeer instructief artikel. Overigens bespeur ik in zijn beoordeling een zekere tweeslachtigheid; zo, wanneer hij betwijfelt of een devaluatie van de gulden in 1931 wel die voordelen zou hebben gebracht, die men achteraf ervan verwachtte, maar aan de andere kant ook van mening is, dat het monetaire beleid en het uitstel van de devaluatie Nederland heeft geïsoleerd. De hoofdthese van zijn betoog, namelijk dat de structurele aard van de crisis de regering na 1933 weinig keuze liet en niet één-twee-drie door een ander beleid had kunnen worden weggenomen, wordt eveneens ietwat afgezwakt, doordat ook Klein zelf het beleid van Colijn en Oud als star, traag en visieloos afschildert. De vraag is immers of volgens zijn interpretatie van de ware oorsprong van de crisis - de achtergebleven economische en technologische structuur - een ander voortvarender beleid na 1933 iets wezenlijks had kunnen veranderen. $\mathrm{Nu}$ moeten we concluderen, dat de crisis aan de ene kant, gezien de structuur, nauwelijks te bezweren viel, maar dat aan de andere kant, geheel los daarvan, het land met een regering was gezegend, die haar taak niet op adequate wijze wist te vervullen. Doch wanneer het eerste waar is, wordt het tweede irrelevant.

30. Vergelijk O. Vries, 'De Vrijzinnig-Democratische Bond als factor in de Nederlandse politiek (1917-1933)', Bijdragen en Mededelingen betreffende de Geschiedenis der Nederlanden, LXXXVIII (1973) 444 en Vonhoff, Zindelijke burgerheren.

31. De partijprogramma's zijn te vinden in het jaarboekje Parlement en Kiezer, J. A. Jungman en F. K. van Iterson, ed. (Den Haag: Martinus Nijhoff). 
souvereiniteit blijven verwerpen. De ARP verkondigt nog in 1938, dat de principes van de Franse revolutie als noodlottig bestreden dienen te worden. Ook herhalen ARP en CHU met vrijwel dezelfde bewoordingen elk en met verwijzingen naar vorige programmas, dat Nederland een christelijk-protestantse natie is en Oranje door God met de historische leiding begiftigd. De overheid is voorts dienaresse Gods, hem alleen verantwoording verschuldigd; al worden grondwet en constitutionele monarchie uitdrukkelijk aanvaard als het kader, waarbinnen het nationale leven zich dient te voltrekken ${ }^{32}$.

Bij de liberalen is van dit alles natuurlijk geen sprake, noch van Gods souvereiniteit, noch van Oranjes historische roeping. In de beginselverklaringen van de Vrijheidsbond kunnen we lezen, dat de scheppende kracht van de persoonlijkheid de bron van alle vooruitgang is ${ }^{33}$. Tot zover lijkt de antithese allerminst begraven.

Maar de praktische standpunten en politieke consequenties, die beide kampen uit hun theoretische uitgangspunten trekken, ontlopen elkaar nauwelijks: handhaving van orde en gezag; het wordt door de liberalen met niet minder nadruk herhaald dan door de confessionelen, de katholieken incluis. Dat betekent bestrijding van alle revolutionaire of maatschappijveranderende activiteiten. Staatsonthouding zo veel mogelijk in sociaal en economisch opzicht. 'De overheid is niet geroepen een ieder een bestaan te verzekeren, maar wel het verkrijgen daarvan zoveel mogelijk te vergemakkelijken' heet het voorbeeld in het program van beginselen van de CHU uit 1908, dat met kleinere wijzigingen telkens in de jaren dertig wordt herhaald ${ }^{34}$. Onmiskenbaar met het oog op radikalisering pleiten confessionelen en liberalen voor een krachtig uitvoerend bewind en voor wijze zelfbeperking van het parlement. Het parlement ... eens de oogappel van de liberalen, de spil van de liberale staatsconceptie; het wordt nu als een institutie beschouwd, die de regering bij haar zware taak vooral niet te veel aan de kop moet zeuren, die haar veeleer met raad en daad terzijde moet staan; geen argwanende controleur van de kroon, maar een weimenende adviseur. Tenslotte de koloniale politiek: ook hier grote eensgezindheid; handhaving van het gezag en vaderlijke zorg voor de inlanders, die aan Nederlands leiding zijn toevertrouwd!

We moeten nog even op het parlement terugkomen. In zijn boek Crisis en critiek der democratie heeft A. A. de Jonge ${ }^{35}$ laten zien, dat er in bepaalde kringen na 1918 zichtbaar onvrede heerste met het parlementaire stelsel. Dezelfde klachten in zekere zin, die ons ook vandaag weer vertrouwd in de oren klinken: een logge machinerie, die door de veelheid van partijen en belangen vaak tot immobilisme leidt en ook de regering weinig speelruimte laat. Maar bovenal geen contact tussen

32. Ibidem (1937-1938) 61.

33. Ibidem, 93.

34. Ibidem (1932-1933) 75.

35. A. A. de Jonge, Crisis en critiek der democratie (Assen, 1968). 


\section{H. W. VON DER DUNK}

volksvertegenwoordiging en volk. De staatstaak was ook na 1918 al enorm gewassen in vergelijking met de vorige eeuw en vereiste steeds meer deskundigheid en specialistendom ook in het parlement. A. Lijphart heeft in dit verband de these opgesteld, dat de verzuiling van het politieke leven tot een pacificatie aan de top, tot een stilzwijgende samenwerking van de politieke elites van de verschillende zuilen heeft geleid $^{36}$. Wat confessionelen en liberalen betreft is dat evident en ook de SDAP - hoe zeer ook nog officieel gewantrouwd - tracht toch in toenemende mate de elites duidelijk te maken, dat ze bereid is mee te werken en haar oude klauwen in te trekken ${ }^{37}$. De kritiek op deze onbevredigende en ondoorzichtige gang van zaken - een koehandel van de elites achter de fassade van een immobiel en immobiliserend parlement - kon nu tot zeer tegenovergestelde conclusies leiden, zoals De Jonge eveneens laat zien. Men kon naar middelen zoeken om het beginsel van de democratie zuiverder tot zijn recht te laten komen. Men kon ook achter dat beginsel zelf vraagtekens zetten. De oude weerstand tegen een op algemeen kiesrecht gebaseerde democratie vond nieuw voedsel in het haperende parlementaire stelsel na 1920. Ook hierbij kwam er een toenadering tussen ontevreden confessionelen en ontevreden liberalen. Een van de eerste openlijke en onbewimpelde bestrijders van het parlementarisme al voor de eerste wereldoorlog, was een oudliberaal: J. H. Valckenier Kips ${ }^{38}$. Onder de Vrije Liberalen bevonden zich meer van zijn gading. Ook Bolland en zijn aanhangers, waarvan laatste uitlopers als B. Wigersma ${ }^{39}$ en ir. J. Frijling ${ }^{40}$ in de jaren dertig de uitgesproken anti-democratisch autoritaire 'Waag-reeks' zouden opzetten, wortelden in het liberalisme, dat zich na de eeuwwisseling - zoals al gememoreerd - zo duidelijk gaat opsplitsen in een anti-sociale, star-behoudende en een progressieve vleugel ${ }^{41}$. Figuren als Valckenier Kips bewijzen, hoezeer het liberalisme voor sommigen tot een autoritair maatschappelijk status-quo-denken was geworden.

$\mathrm{Na}$ de invoering van het algemeen kiesrecht vindt er nu een toenadering plaats tussen de anti-democraten uit het confessionele en uit het liberale kamp. En deze figuren propageren bewust de afbraak van de antithese. Verzamelplaatsen van deze malcontenten waren 'Het Vaderlandsch Verbond' en de in 1925 daaruit voortgekomen 'Nationale Unie'. In het 'Staatkundig Advies', dat in 1925 werd gepubliceerd als open brief aan de partijen, ondertekend door ruim tweehonderd personen uit de gegoede en deftige bovenlaag staat het in alle duidelijkheid:

36. A. Lijphart, Verzuiling, pacificatie en kentering in de Nederlandse politiek (Amsterdam, 1966). 37. Vergelijk I. Cornelissen, e. a., De taaie rooie rakkers (Utrecht-Baarn, 1965). Over de interne discussies binnen de SDAP vond ik gegevens onder andere in een doctoraalscriptie van A. Arendsen, 'Van ideologie naar program' (Utrecht, 1973).

38. De Jonge, Crisis, 32 .

39. B. Wigersma, Parlementarisme of dictatuur? (Bussum, 1933).

40. J. Frijling, De onvermijdelijkheid eener autoritaire regering (Bussum, 1936). Verder diverse artikelen van Wigersma en Frijling in De Waag, I en II (Bussum, 1937-1938).

41. De Jonge, Crisis, 45, 216, 236, 315, 321. 
Wij erkennen het christelijk karakter van ons volksleven als den historischen grondslag onzer nationale beschaving en aanvaarden den liberalen staat als het kader, waarbinnen dit karakter zich onbelemmerd in alle richtingen kan ontwikkelen ${ }^{42}$.

Het is dan vooral prof. mr. J. A. Eigeman geweest - docent in de staatswetenschappen aan de Hogere Krijgsschool met de persoonlijke titel van hoogleraar - die in verschillende publicaties in de jaren twintig en dertig uit dat zelfde vaatje tapt. Ik noem alleen een boek uit 1935, waarvan de titel aan duidelijkheid niets te wensen overlaat: Colijn, de verbinding tusschen Thorbecke en Groen ${ }^{43}$. De tijd van het parlementarisme is voorbij, leert Eigeman. Colijn is de man, die de onzalige antithese tussen Thorbecke en Groen - in Eigemans ogen een soort tragisch misverstand - kan en zal overwinnen. Het liberalisme is na Thorbecke op een dwaalspoor geraakt. De liberalen hadden zich niet gehouden aan hun beginsel en opdracht, te weten de vestiging van de neutrale staat. Zij hadden die staatsvorm vol willen gieten met de modernistische onchristelijke geest van de negentiende eeuw, die geest van materialisme en intellectualisme. Daardoor hadden zij de confessionelen in het harnas gejaagd. Maar christendom en liberalisme zijn in wezen één, zo besluit Eigeman: het ware liberalisme dan, dat niet een vrucht van de Franse revolutie was, maar van de reformatie. Thorbecke dient als kroongetuige. Die had er in zijn conflict met Groen op gewezen, dat de liberale staat van huis uit en vanzelfsprekend een algemeen christelijke staat was, omdat hij wortelde in de christelijk-nationale traditie en cultuur.

We zien in deze jaren een steeds bewustere herinterpretatie van het liberalisme en vooral van Thorbecke bij hen, die zich voor een christelijk-liberale synthese beijveren. Thorbecke verschijnt als de ware liberaal, die tijdig had willen stoppen, die de volkssouvereiniteit verwierp, die kroon en parlement scherp gescheiden wilde houden en in dat laatste een soort jury van gezworenen zag, onafhankelijk bovenal van het kiezersvolk. Thorbecke, de juste-milieu-man, die een geheel eigen, niet atomistische maar organische staatsconceptie er op na hield! Zo schreef L. W. G. Scholten in een artikel 'Thorbecke en Guizot' in Themis in 1935: 'Thorbeckes vragen zijn onze vragen. Zijn probleemstelling is onze probleemstelling. Zijn staatkundige visie is nog in vele opzichten modern' ${ }^{\prime 4}$. Ook F. C. Gerretson, de drijvende intellectuele kracht achter de 'Nationale Unie' doet pogingen om tot een herwaardering van Thorbeckes liberalisme te komen, althans om er aanknopingspunten in te vinden voor zijn ideaal van sterke koninklijke kabinetten. Zijn befaamde open brief aan Colijn van 1933 ('Koninklijk Kabinet of Dictatuur'?) is

42. Geciteerd in ibidem, 95.

43. J. A. Eigeman, Colijn, de verbinding tussen Thorbecke en Groen (Rotterdam, 1935). Ook De Jonge, Crisis.

44. L. W. G. Scholten, 'Thorbecke en Guizot', Themis (1935). 
één lang, vrij ingewikkeld juridisch betoog, om aan te tonen, dat Thorbeckes grondwet koninklijke kabinetten, zoals Gerretson ze verstaat, toelaat ${ }^{45}$.

En Colijn zelf, de held van Eigeman en Gerretson, de held van het protestantse kiezersvolk? Ook hij proclameert 'de liberale staat'. Hij was de plaatsvervangende held voor de liberalen geworden. De nostalgie naar het midden van de negentiende eeuw, naar de tijd van Thorbecke, toen een regering nog uitsluitend te maken had met een overzichtelijke beschaafde bovenlaag, toen industrialisatie en massademocratie de staat nog niet voor ingewikkelde problemen van ingrijpen of bijsturen hadden gesteld, die nostalgie dreef nu oudliberalen en protestanten naar elkaar toe. Het is bekend, dat de roep om 'herstel van het gezag' in 1933 ineens een ongekende geluidsterkte bereikte naar aanleiding van de muiterij van de 'Zeven Provinciën' ; een incident, dat meer dan iets anders een scherp licht in de buikholte van de Nederlandse samenleving werpt. Dat dit mogelijk was, in 'ons Indië' nog wel, schokte brede kringen van de bevolking meer dan de hele depressie of Hitlers greep naar de macht. Het nationale bewustzijn was aangeslagen: ook Nederland bleek niet die rots van rust en fatsoen te zijn in een op drift geslagen wereld, die de meesten er nog in hadden gezien.

In de opvattingen van kringen als 'Het Vaderlandsche Verbond', de 'Nationale Unie' of het 'Verbond van Nationaal Herstel' vinden we nu veel terug van de bekende conservatieve staats- en maatschappijopvatting: de voorkeur voor een sterk personalistisch gekleurd uitvoerend bewind, het afwijzen van het parlementaire stelsel, het 'demo-liberalisme' als atomistisch en gezagsondermijnend, het afwijzen van de massademocratie, het heimwee naar de negentiende eeuw en het nationale verleden in het algemeen, het propageren van een organische ordening. We vinden ook, dat deze kringen hun aanhangers recruteerden uit de betere standen van christelijk-protestantse of van oud-liberale signatuur. We vinden voorts de openingen naar het fascisme of naar fascistoïde bewegingen, die we ook in andere landen aantreffen bij wanhopige conservatieven, die op zoek zijn naar een bredere achterban in hun benauwdheid voor het rode alternatief. In Nederland echter kan bij de meesten van een volledig afglijden naar het fascisme niet worden gesproken. Men had in restauratieve kringen veel belangstelling, ook getemperde sympathie voor het fascistische experiment van Mussolini, maar vond toch dat Nederland het in een andere richting, conform de eigen nationale traditie, moest zoeken. Wat vooral velen in het fascisme afstootte, was het etatisme. De conservatieven in Nederland, van confessionele evenals van liberale signatuur, maakten een verschil tussen 'staat' en 'gezag'. 'Staat' had een onaangename klank. Voor de confessionelen riep dat begrip associaties op met onpersoonlijk, onchristelijk bureaucratisme en modernisme. Hier werkte stellig ook de anti-liberale traditie uit Kuypers dagen nog

45. F. C. Gerretson, Koninklijk kabinet of dictatuur? Open schrijven aan dr. H. Colijn nopens een actueel vraagstuk van staatkunde en staatsrecht (Den Haag, 1933). 
door. Doch de relatie van de liberalen tot de staat was eveneens tweeslachtig. De klassieke liberale leer was immers anti-etatistisch, ook anti-centralistisch geweest en de Nederlandse liberalen hadden zich in hun emancipatiefase op de Loevesteinse traditie beroepen. Later, toen zij de liberale staat hadden opgericht, werd de instelling weliswaar positiever. Maar een oude huivering voor staatsalmacht en staatsbemoeienis bleef toch ook in onze eeuw het liberale denken eigen. De spirituele, ja mystieke wijding, die het Duitse woord 'Staat' uitstraalt, mist het Nederlandse equivalent ten enenmale. Nog nooit voelde een Nederlander bij die term een rilling van verrukking langs zijn rug lopen.

Opmerkelijk blijft inmiddels, dat ook tijdens de crisis de restauratieve kringen, die zich anti-democratisch opstelden en die met fascistische denkbeelden koketteerden, een kleine onderling verbrokkelde minderheid bleven, zoals ook het fascisme zelf in Nederland nooit werkelijk een bedreiging van de democratie vermocht te vormen.

Het ligt voor de hand om hier een verband te zien met de zwakte, zo niet afwezigheid van een feodaal-agrarisch conservatisme. Het fascisme betekende overal een teruggrijpen op pre-industriële aristocratische denkvormen en waarden door gedeklasseerden, afvalelementen en ontwortelden uit een moderne burgerlijk-industriële samenleving. Waar die denkvormen en dat verleden ontbraken, was de brede basis voor een succesvolle fascistische beweging ergo evenmin gegeven, zelfs niet in een crisis. De zwijgende samenwerking tussen confessionelen en liberalen op grond van een omvattende consensus bleek taai en hecht genoeg om het succes van restauratieve en fascistische krachten maar evengoed van links-revolutionaire krachten te beletten. Het was een consensus, die we zonder aarzeling conservatief noemen; uitdrukking van het typisch Nederlandse conservatisme wel te verstaan: het stedelijk-burgerlijke, dat in de negentiende eeuw in het confessionele kamp, later ook bij de liberalen reliëf krijgt - hoe verschillend, ja dikwijls zelfs antagonistisch ook de ideologische standpunten waren -. Maar in het Interbellum hadden beiden elkaar gevonden in hun vastbeslotenheid om de status quo te handhaven tegen alle bedreiging. Natuurlijk van links, maar ook van rechts. Rechts wil dan zeggen: de restauratieve of fascistische groeperingen, die zich zonder het te willen en misschien ook te weten, niet op dit stedelijk-burgerlijke inspiratiebeeld oriënteerden maar op een buitenlands verleden. Tenslotte zijn er evengoed alternatieve concepties van een geïdealiseerd verleden als van een geïdealiseerde toekomst.

Die consensus is niet in strijd met de befaamde, beruchte verzuiling, die met grote hoofdletters boven heel de Nederlandse verhoudingen tijdens het Interbellum prijkt. Die verzuiling belette immers, dat de consensus van de conservatieven tot opgave van de eigen identiteit zou voeren. Zij was juist een voorwaarde, gezien de Nederlandse tradities en verhoudingen. Omgekeerd belette de consensus, dat de verzuiling 
tot nationale desintegratie zou voeren, zoals Lijphart, naar mijn mening terecht, al eerder heeft gesteld ${ }^{46}$.

Nogmaals ervan uitgaand dat conservatisme vele vormen en vele houdingen kan aannemen, afhankelijk van het verleden, waar het op teruggrijpt of de status quo, die het wenst te behouden, kunnen we concluderen dat het typisch Nederlandse stedelijk-burgerlijke conservatisme juist tijdens het Interbellum via de confessionele en de liberale partijen een ijzersterke dam vermocht op te werpen tegen grote sociale en politieke verschuivingen; daarbij geïnspireerd door een nationaal verleden, waar confessionelen én liberalen zich beiden in thuis konden voelen. Doch omdat de term 'conservatief' hier verbonden werd óf met het ongeïnspireerde en daardoor eng-egotistische behoudsconservatisme van een notabelenkaste uit de negentiende eeuw of met het buitenlandse monarchaal-aristocratische conservatisme, werd hij een vies woord. In dit opzicht dringt zich de parallel met de Verenigde Staten op. Ook daar een stedelijk-burgerlijk conservatisme, dat zich niet alszodanig wenste te zien, omdat het woord geassocieerd werd met Europees-feodale, ergo on-Amerikaanse verhoudingen. Waar een natie en een. nationale identiteit pas opkwam na en tengevolge van een revolutie tegen een monarchale orde, kon het feodaal-aristocratische conservatisme minder gemakkelijk aarden en raakte de term al gauw besmet.

Dat hier slechts enkele algemene lijnen konden worden getrokken spreekt vanzelf. Lijnen, die nog onnoemelijk veel verder uitgewerkt en verfijnd zouden moeten worden. Zo is het katholicisme in de Nederlandse samenleving, dat ook een conserverende functie kreeg, nadat het samen met het protestantisme met succes de liberale staat had bestreden en tot de emancipatie van grote bevolkingsgroepen had bijgedragen, niet besproken. Evenmin ben ik dieper ingegaan op de diverse antidemocratische herstelbewegingen en op de corporatistische denkbeelden, die we als alternatief tot de rationalistisch-parlementaire staat tegenkomen.

De vraag naar het conservatisme in naoorlogs Nederland tenslotte zou een aparte behandeling vragen. In hoeverre vond er een verkapte restauratie plaats en in hoeverre ging het daarbij om een algemeen West Europees verschijnsel als reactie op het Oost-West conflict na 1945 en op de dekolonisatie? Waarom is de grote doorbraak van het Nederlandse partijleven toen blijven steken en kwam in de tweede helft van de jaren zestig - ook alweer binnen een algemeen Westerse vernieuwingsbeweging - de grote reactie tegen die naoorlogse restauratie op gang, waar we nog midden in zitten? De vraag naar het conservatisme en zijn verschijningsvormen staat ook bij al deze kwesties centraal. Ook vandaag kan men met een lantaren zoeken naar partijen of politici, die zich 'conservatief' noemen of die hun politiek als 'conservatief' trachten te verkopen. Het woord lijkt, zeker in progressieve kring, nog erger besmet dan vóór 1940 door algemene vage maar zeer 46. Vergelijk Lijphart, Verzuiling. 
aanwezige associaties met het fascisme, dat zijn opkomst en succes in Europa stellig ook aan conservatieve krachten had te danken. Bovendien zullen, anders dan vijftig jaar geleden, nog maar zeer weinigen luidkeels zingen, dat ze niet zullen buigen voor de goden van de tijd. Eerder strekt het tot aanbeveling om te buigen, dat de gewrichten kraken. Nederland heeft zich in het laatste decennium ontwikkeld tot het meest anti-traditionalistische land van het Westen en de roep om een bewust actief conservatisme, dat niet vol schaamte het gezicht bedekt, is dan ook zeer verklaarbaar. Zelfs progressieven of zij die zich gisteren nog alszodanig beschouwden, hijgen achter de ontwikkeling aan en hebben moeite hun zelfportret realistisch te corrigeren. Maar daarmee is in feite slechts gezegd, dat conservatisme ook vandaag aanwezig blijft omdat de menselijke huishouding een zeker evenwicht aan impulsen niet kan missen. Zoals tot diep in de achttiende eeuw revolutionaire denkbeelden een conservatieve verpakking meekregen, zo geeft men vandaag eventuele conservatieve denkbeelden graag een progressieve verpakking mee. Een neiging, die door de consumptiemaatschappij natuurlijk in allerhoogste mate is bevorderd; een maatschappij, die tot dogma heeft: nieuw is goed. Maar het gaat tenslotte niet om de verpakking. Wanneer in Nederland het conservatisme zich niet vermag te organiseren, waarbij de hier behandelde afwezigheid van een feodaal-agrarische traditie in het verleden als voornaamste oorzaak moet worden aangewezen, dan zal het zich op andere wijze binnen de diverse partijen en groeperingen doen gelden, waarbij niet alleen de liberalen maar ook de socialisten nolens wiens gedwongen zouden kunnen worden een conservatieve en conserverende functie uit te oefenen naast de confessionelen. De scheidslijnen lopen al lang dwars door de partijen heen; het sterkste bewijs dat conservatisme continu werkzaam is, in telkens andere maskers en costumeringen ongetwijfeld, maar hoe dan ook present. 


\section{Feminisme in België. De eerste vrouwelijke artsen (1873-1914)}

\section{KEYMOLEN}

\section{INLEIDING}

In de negentiende eeuw ontstond er in de Verenigde Staten van Amerika en in Europa een beweging die gelijke rechten voor de vrouw opeiste. De georganiseerde vrouwenbeweging startte in Amerika. In 1848 werd op initiatief van Elizabeth Cady Stanton de eerste 'Women's Rights Convention' gehouden in Seneca Falls te New York. De oprichting van de eerste feministische organisaties van betekenis in Europa vond plaats tussen 1860 en 1870. In Engeland was sinds 1860 sprake van een georganiseerde vrouwenbeweging; Duitsland volgde in 1865; de 'Ligue française pour le droit des femmes' werd in 1870 opgericht en de organisaties in Nederland en België dateren van 1872 en 1892. De feministen eisten gelijke rechten op het gebied van arbeid, onderwijs en burgerrechten.

Eén aspect van de vrouwenemancipatie zullen wij nader belichten: het openstellen van het medisch beroep voor de vrouw in België en de lotgevallen van de eerste vrouwelijke artsen.

In de Verenigde Staten werd Elizabeth Blackwell in 1849 de eerste gediplomeerde vrouwelijke arts. In 1850 opende men te Philadelphia het eerste medisch college voor vrouwen. Ofschoon de universiteiten zelf hun leergangen aarzelend openstelden voor studentes, nam het aantal vrouwelijke dokters in Amerika snel toe dank zij de oprichting van nog meer speciale scholen. Een kortstondig Russisch experiment niet te na gesproken, stelde de universiteit van Zurich als eerste Europese onderwijsinstelling in 1864 haar leergangen in geneeskunde open voor studentes. De hogeschool van Bern volgde dit voorbeeld in 1872. Buitenlandse meisjes maakten in deze eerste jaren dankbaar gebruik van de geboden kansen in Zwitserland. Parijs besloot in 1868 vrouwelijke kandidaten voor medische studies te aanvaarden en reikte in 1870 het eerste doktersdiploma uit aan de Engelse miss Garreth. De eerste afgestudeerde vrouw in Nederland was Aletta Jacobs. Zij wist in 1871 op voorspraak van Thorbecke toestemming te krijgen tot het volgen van colleges aan de rijksuniversiteit te Groningen. In 1878 legde zij het artsexamen af, in 1879 promoveerde ze en vervolgens vestigde ze zich als arts te Amsterdam. Daar de Britse medische faculteiten weerstand bleven bieden, opende men in 1874 in Londen eindelijk een speciale school voor vrouwelijke aspirant-dokters ${ }^{1}$.

1. M. Lipinska, Histoire des femmes médecins depuis l'antiquité jusqu'à nos jours (Parijs, 1900); 